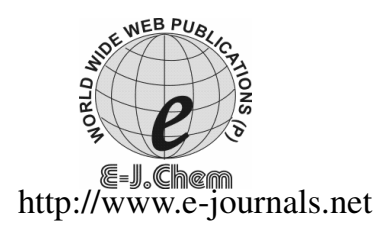

ISSN: 0973-4945; CODEN ECJHAO

E-Journal of Chemistry

2012, 9(1), 240-252

\title{
Adsorption Characteristics of Polyvinyl Alcohols in Solution on Expanded Graphite
}

\author{
XIU-YAN PANG \\ College of Chemistry and Environmental Science \\ Hebei University, Baoding 071002, People' Republic of China \\ pxy833@163.com
}

Received 21 January 2011; Accepted 12 April 2011

\begin{abstract}
Expanded graphite (EG) adsorbent was prepared with 50 mesh graphite as raw materials, potassium permanganate as oxidant, and vitriol as intercalation compound. Three kinds of polyvinyl alcohol (PVA) with different degree of polymerization (DP) in aqueous solution were used as adsorbates. We have studied the influence of initial PVA concentration, temperature and ionic strength on adsorption capacity. Langmuir constants and Gibbs free energy change $\left(\Delta \mathrm{G}^{\circ}\right)$ were calculated according to experimental data respectively. Thermodynamic analysis indicates the equilibrium adsorbance of PVA on EG increase with the rise of $\mathrm{SO}^{2-}$ concentration. Adsorption isotherms of PVA with different degree of polymerization are all types and we deduce PVA molecules lie flat on EG surface. Adsorption processes are all spontaneous. Kinetic studies show that the kinetic data can be described by pseudo second-order kinetic model. Second-order rate constants and the initial adsorption rate rise with the increasing of temperature and half-adsorption time decreases with the increasing of temperature. The adsorption activation energy of each PVA is less than $20 \mathrm{~kJ} \cdot \mathrm{mol}^{-1}$, physical adsorption is the major mode of the overall adsorption process.
\end{abstract}

Keywords: Expanded graphite, Polyvinyl alcohol, Adsorption kinetics, Adsorption thermodynamics, Gibbs free energy change, Physical adsorption

\section{Introduction}

Polyvinyl alcohol (PVA) is a sort of widely used polymer in industry and the molecular structure of $\left[-\mathrm{CH}_{2}-\mathrm{CH}(\mathrm{OH})\right]_{\mathrm{n}}$ makes it possess of well water solubility. PVA has many unique characteristics such as strong adhesion, film flexibility, smoothness, oil resistance, solvent resistance, protective colloid, obstruction of gas and abrasion resistance, so it has extensive use in food, medicine, textile, papermaking, agriculture, polymer chemical industry ${ }^{1}$. However, the wasted textile solution may become one of the major wastewater 
sources of PVA, especially in sizing production process ${ }^{2}$. The principal treatment methods of PVA wastewater are biodegradation ${ }^{3-5}$, chemical coagulation ${ }^{6}$ and ultrafiltration technique ${ }^{7,8}$. Lee et $a l^{3}$ isolated PVA-degrading bacteria (SB68+SB69) from various sources such as activated sludge from the water-course of textile and dyeing factories, cultivating soil and leaf mold. They showed high activity for PVA degradation so that $75 \%$ of PVA with an initial concentration of $0.01 \%$ was mineralized during 46 days of the modified Sturm test. A dyeing factory in beijing ${ }^{6}$ made continuous condensation recycling of PVA slurry desizing water of polyester-cotton fabric with $\mathrm{Na}_{2} \mathrm{SO}_{4}(10 \sim 12 \mathrm{~g} / \mathrm{L})$ and Borax $(1 \sim 1.5 \mathrm{~g} / \mathrm{L})$ under temperature $40 \sim 50{ }^{\circ} \mathrm{C}$, both of PVA condensate recovery and wastewater COD removal rate achieved $80 \%$. With hollow fiber ultra-filtration membrane equipment ${ }^{8}$, Dong studied the influence of liquid running time, pressure on both sides of membrane, liquid temperature and mainstream flow rate et al on filter flux and rejection rate, gained optimum conditions of PVA desizing wastewater.

In wastewater treatment, it is well known that adsorption process has been considered available method for eliminating organic pollutants. Adsorption of PVA on adsorbents such as silica, polystyrene particles, kaolin, fuller's earth, montmorillonite and powered activated carbon has been studied ${ }^{9-14}$. Adsorption of PVA on silica illustrated silanols and siloxane bonds were the main adsorption sites. Very low affinity was found between PVA and kaolin minerals. At fixed $\mathrm{pH}$ (4.8) and ionic strength of the medium, adsorption isotherm for PVA on fuller's earth surfaces resembles with LIII type. The maximum adsorbance of PVA ( $\mathrm{pH}=6$ ) on montmorillonite Ca-Mt was $151.2 \mathrm{mg} / \mathrm{g}$, which is considerably lower than that on Na-Mt (496.2 $\mathrm{mg} \mathrm{g}^{-1}$ ). Adsorption isotherm of PVA on powered active carbon was similar with $H$-type and the maximum removal of $92 \%$ was obtained at a $\mathrm{pH}$ of 6.3 and contact time of $30 \mathrm{~min}$ for an adsorbent dose of $5 \mathrm{~g} / \mathrm{L}$.

Expanded graphite (EG) is a kind of porous adsorbent; it can be easily prepared with chemical method or electrical chemical method through oxidation and intercalation reaction. The pore in EG ranges from several $\mathrm{nm}$ to hundreds $\mu \mathrm{m}^{15}$, it has been used as absorbent for its high adsorption capacity for organic materials, such as heavy oil and biomedical molecules ${ }^{16-21}$. Pang et al have studied the adsorption capacities of EG for oil, dyes, aromatic sulfonates, polyethylene glycol $(\mathrm{PEG})^{22-25}$, results indicated EG show definite adsorption capability for these organic substances, especially for oils. Both adsorbates molecular weight and molecular structure affected adsorption type, saturation adsorbance.

The aim of this work is to study the adsorption thermodynamics and adsorption kinetics characteristics of PVA on EG in water solution. Investigate the effect of ionic strength, adsorbate concentration, temperature on adsorption capacity and do further evaluation of applicability of common isotherm model (i.e., Langmuir and Freundlich) and pseudosecond-order rate model. In the research, PVA with different PDs of 500, 700 and 1750 in aqueous solution are investigated.

\section{Experimental}

With the mass ratio of 1: 0.12: 5.0 of graphite (C): $\mathrm{KMnO}_{4}: \mathrm{H}_{2} \mathrm{SO}_{4}(96 \%)$, the definite amount of $\mathrm{C}, \mathrm{KMnO}_{4}$ and $\mathrm{H}_{2} \mathrm{SO}_{4}$ (diluted to a mass concentration of $50 \%$ with de-ionized before mixed with graphite) were mixed under room temperature. The reaction lasted $30 \mathrm{~min}$ under stirring, then products were washed with de-ionized water until $\mathrm{pH}$ reached to $6.0 \sim 7.0$. After filtration and dryness under $80{ }^{\circ} \mathrm{C}$, the solid scalelike grains were heated under $900{ }^{\circ} \mathrm{C}$ for about $10 \mathrm{sec}$ and then EG could be gained. The pore distribution of the prepared EG is detected by autopore II 9220 mercury porosimeter (Micromeritics Inc. USA) under the condition of 0.58 1301PSIA. Results given in Table 1 show pores in EG are mainly micron pore. 
Table 1. Structural parameter of EG

\begin{tabular}{|c|c|c|c|c|c|c|}
\hline \multirow{2}{*}{ 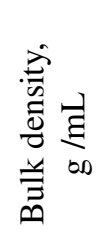 } & \multirow{2}{*}{ 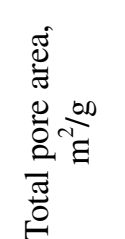 } & \multirow{2}{*}{ 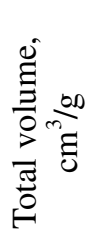 } & \multicolumn{4}{|c|}{ Distribution of pore volume, $\mathrm{mL} / \mathrm{g}$} \\
\hline & & & $\begin{array}{c}\sim 1037 \\
\mathrm{~nm}\end{array}$ & $\begin{array}{c}1037 \sim 10072 \\
\mathrm{~nm}\end{array}$ & $\begin{array}{c}10072 \sim 112689 \\
\mathrm{~nm}\end{array}$ & $\begin{array}{c}112689 \sim 313584 \\
\mathrm{~nm}\end{array}$ \\
\hline 0.0308 & 1044.99 & 30.11 & 1.3693 & 7.4544 & 15.8525 & 3.6583 \\
\hline
\end{tabular}

\section{Adsorbates characteristic}

Adsorbates used in experiments are PVA with different DPs of 500, 700, 1750, respectively. PVA-1750 is general commercial, PVA $(500,700)$ of expected polymerization degree were prepared through the degradation of polyvinyl alcohol 1750 with $\mathrm{H}_{2} \mathrm{O}_{2}$ under different $\mathrm{pH}$, and its molecular weight was detected with ubbelohde viscometer ${ }^{26}$. Simulated PVA wastewaters are prepared by dissolving PVA in distilled deionized water at various concentrations. In quantitative analysis ${ }^{27}, \mathrm{H}_{3} \mathrm{BO}_{3}-\mathrm{I}_{2}$ in solution is used as colored reagent of PVA and absorbance of the colored complex (color reaction lasted $15 \mathrm{~min}$ ) is detected with T6 new century UV spectrophotometry (Puxi Tongyong Instrument Limited Company of Beijing). Absorbance values are recorded at the wavelength for maximum absorbance $\left(\lambda_{\max }\right)$ (Table 2) and its solution is initially calibrated for concentration in terms of absorbance units.

Table 2. DP and maximum absorbance wavelength of PVA

\begin{tabular}{cccc}
\hline PVA & 500 & 700 & 1750 \\
\hline$\lambda_{\max }, \mathrm{nm}$ & 646 & 646 & 646 \\
\hline
\end{tabular}

\section{Static adsorption of $P V A$}

$0.20 \mathrm{~g}$ of EG is mixed in different conical glass flasks with $100.0 \mathrm{~mL}$ solution at the desired PVA concentration and ionic strength. Ionic strength is adjusted with $\mathrm{NaCl}$ or $\mathrm{Na}_{2} \mathrm{SO}_{4}$ solution. Mass of EG to volume of solution is standardized as $M / V=0.200 / 0.1=2.0 \mathrm{~g} / \mathrm{L}$. PVA concentration changes are recorded with spectrophotometer at $\lambda_{\max }$ and equilibrium adsorbance is determined according to equation (1).

$$
q_{e}=V\left(C_{0^{-}} C_{e}\right) / M
$$

$q_{e:}$ Equilibrium adsorbance of PVA on EG, $\mathrm{mg} / \mathrm{g} ; C_{0:}$ Initial concentration of PVA in solution, $\mathrm{mg} / \mathrm{L} ; C_{e}$ : Equilibrium concentration of PVA in solution, $\mathrm{mg} / \mathrm{L} ; V$ : Volume of solution, $\mathrm{L} ; M$ : Mass of EG, $\mathrm{g}$

\section{Adsorption kinetics of $P V A$}

Adsorption kinetics experiments are carried out using a HZS-D shaking water bath (Donglian Haerbin, China). A series of desired PVA concentration and fixed $100.0 \mathrm{~mL}$ are placed in vessels, where they are brought into contact with EG at $25{ }^{\circ} \mathrm{C}, 35^{\circ} \mathrm{C}$ and $45^{\circ} \mathrm{C}$, respectively. Amount of PVA captured by EG at different time is determined according to equation (2):

$$
q_{t}=V\left(C_{0^{-}} C_{t}\right) / M
$$

$q_{t}$ : Accumulative adsorbance of adsorbate on EG at the moment of $\mathrm{t}, \mathrm{mg} / \mathrm{g} ; C_{t}$ : concentration of PVA in solution at the moment of $\mathrm{t}, \mathrm{mg} / \mathrm{L}$; 


\section{Results and Discussion}

\section{Adsorption isotherm and thermodynamic parameters}

Static adsorption capacities of EG for PVA (500, 700, 1750) are measured. Figure 1 (a) and (b) illustrates a typical I type isotherm. Equilibrium adsorbances are less than $20 \mathrm{mg} / \mathrm{g}$ among the detected PVA solution and it decrease with the increase of PVA' DP. The results are just as the adsorption of linear PEG on $\mathrm{EG}^{25}$. The planar structure and large molecules of PVA might form certain kinds of conformation on the surface of EG, which might reduce the adsorbed sites and make the further adsorption difficult.
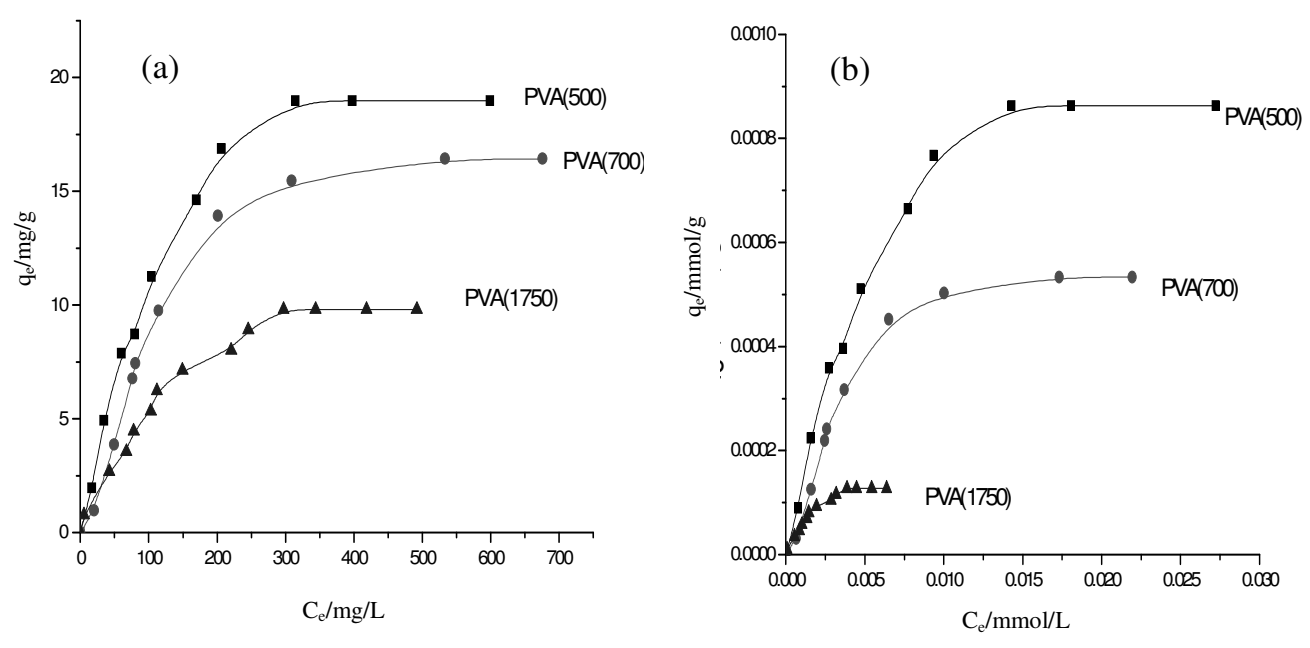

Figure 1. Adsorption isotherm of PVA $(500,700,1750)$ at $25^{\circ} \mathrm{C}$, (a) Unit of adsorbance is $\mathrm{mg} / \mathrm{g}$; (b) Unit of adsorbance is $\mathrm{mmol} / \mathrm{g}$

To providing a description of PVA concentration and possible conformation in the interfacial region, Langmuir and Freundlich isotherm equations (3) and (4) are used to treat the isotherm data. The molecule area $(a)$ of PVA with different DP is calculated according to $q_{0}$ and total pore area. As showed in Table 3, Langmuir isotherm gives a better fit than Freundlich isotherm and the higher DP PVA possessed, the smaller $A$ is gained, the lower equilibrium concentration of PVA corresponding to half saturation adsorbance. This might be caused by the lower water solubility of higher DP of PVA and then cause stronger appetency with EG. At the same time, there is an almost linear relationship between PVA DP and PVA molecule area (Figure 2). We can deduce PVA molecule lies flat on the EG surface $^{25}$.

$$
\begin{aligned}
& \text { Langmuir equation }{ }^{28}: 1 / q_{e}=1 / q_{0}+A \cdot /\left(q_{0} \times C e\right) \\
& \text { Freundlich equation: } \ln q_{e}=\ln K_{F}+(1 / n) \ln C e
\end{aligned}
$$

$q_{0}$ : Maximum adsorption amount of PVA in forming complete monolayer coverage on EG pore surface, $\mathrm{mg} / \mathrm{g}$; $A$ : Equilibrium concentration of PVA corresponding to half saturation adsorbance, $\mathrm{mg} / \mathrm{mL} ; K_{F}$ : Freundlich equation constant; $1 / n$ : adsorption intensity for Freundlich equation. 
Table 3. Langmuir and Freundlich isotherm constants at $25^{\circ} \mathrm{C}$

\begin{tabular}{|c|c|c|c|c|c|c|c|}
\hline \multirow{2}{*}{$D P$} & \multicolumn{4}{|c|}{ Langmuir } & \multicolumn{3}{|c|}{ Freundlich } \\
\hline & $\frac{q_{0}}{\mathrm{mmoL} / \mathrm{g}}$ & $\frac{a}{\mathrm{~nm}^{2} / \mathrm{molecule}}$ & $\begin{array}{c}A \\
\mathrm{mmoL} / \mathrm{mL}\end{array}$ & $r$ & $K_{F}$ & $1 / n$ & $r$ \\
\hline 500 & 0.000863 & 402.286 & 0.00716 & 0.9910 & 0.2966 & 0.7587 & 0.9786 \\
\hline 700 & 0.000534 & 650.136 & 0.00524 & 0.9739 & 0.1598 & 0.8221 & 0.8911 \\
\hline 1750 & 0.000127 & 2733.644 & 0.00275 & 0.9918 & 0.2421 & 0.6599 & 0.9843 \\
\hline
\end{tabular}

a: Area of PEG molecule, $(\mathrm{nm})^{2} /$ molecule; $r$ : Linear related coefficient

Base on temperature and Langmuir constant, adsorption free energy change $\left(\triangle G^{\circ}\right)$ of the adsorption process is calculated according to equation $(5)^{29}$, negative $\Delta G^{\circ}$ (Table 4) indicates that adsorption of these reference compounds on EG are all spontaneous and the higher DP the PVA possessed, the easier adsorption is carried.

$$
\triangle G^{\circ}=-R T \ln b
$$

Where $\mathrm{b}=$ Langmuir equation constant, $\mathrm{b}=1 / \mathrm{A}, \mathrm{mL} / \mathrm{mg} ; \Delta G^{\circ}$ : The free energy change in the adsorption, $k J$.

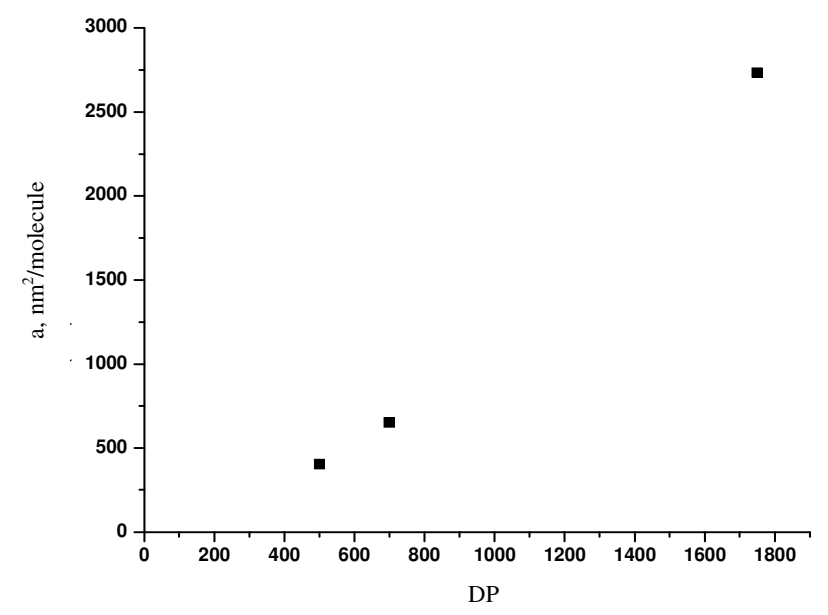

Figure 2. Relationship between PVA, DP and molecule area

Table 4. Free energy change of PVA adsorption on EG at $25{ }^{\circ} \mathrm{C}$

\begin{tabular}{cccc}
\hline$P V A$ & 500 & 700 & 1750 \\
\hline$\Delta G^{\circ} / k J$ & -12.24 & -13.02 & -14.61 \\
\hline
\end{tabular}

\section{Influence of ionic strength on adsorption capacity}

At room temperature, the influence of ionic strength on adsorption capacity is investigated using a $100 \mathrm{mg} / \mathrm{L}$ PVA $\left(500,700\right.$,) solutions which contain $\mathrm{NaCl}$ or $\mathrm{Na}_{2} \mathrm{SO}_{4}$ with ionic strength ranging from 0 to $0.6 \mathrm{~mol} / \mathrm{L}$. The results showed in Figure 3 indicate that the presence of $\mathrm{SO}_{4}{ }^{2-}$ can improve the adsorption capacity of EG for PVA and it may be caused by the electrostatic interaction between PVA and adsorbent, hydrophobic attraction of PVA increases due to the "salting-out" effect. 

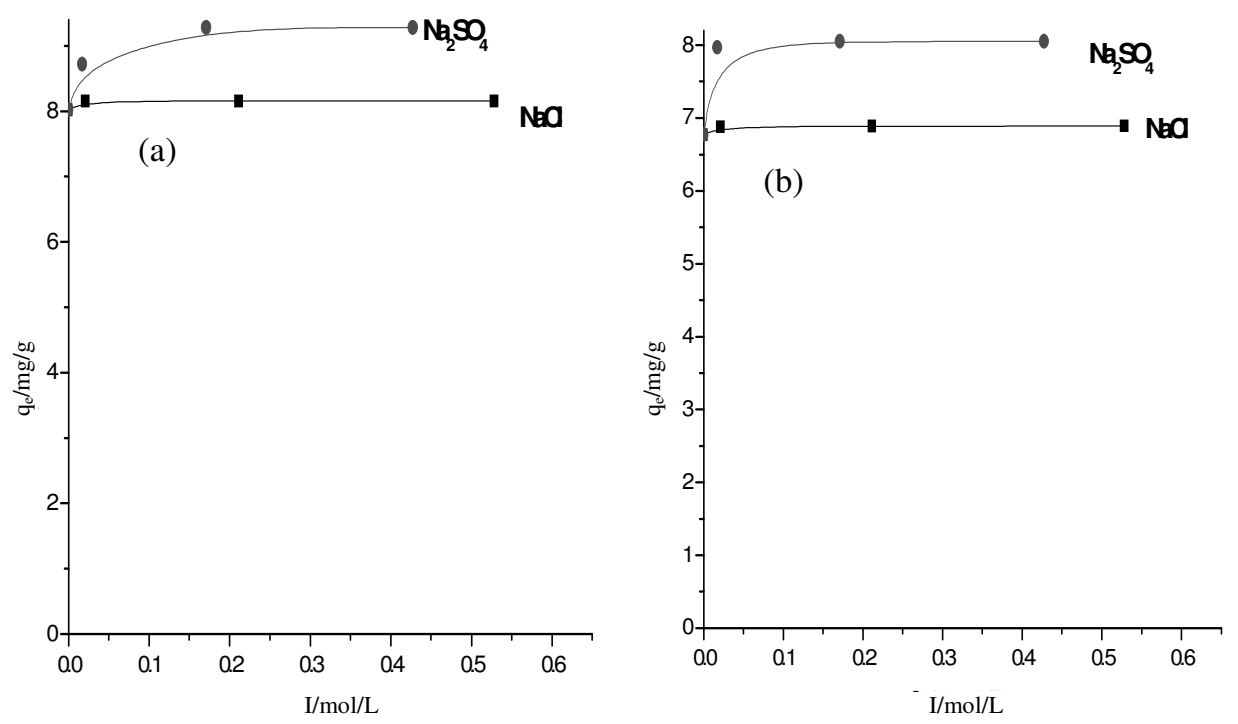

Figure 3. Influence of ionic strength on adsorption capacity of EG for PVA, (a) PVA 500; (b) PVA 700

\section{Adsorption kinetic}

\section{Influence of PVA concentration and temperature on adsorption kinetics}

The influence of PVA $(500,700)$ concentration and temperature on adsorption equilibrium time is detected and showed in Figure $4 \& 5$. Results suggest that adsorbance is the function of PVA concentration, temperature and adsorption time. Equilibrium adsorbances and adsorption rate increase with the increasing of temperature, which might be caused by the change of solution viscosity under different temperature.
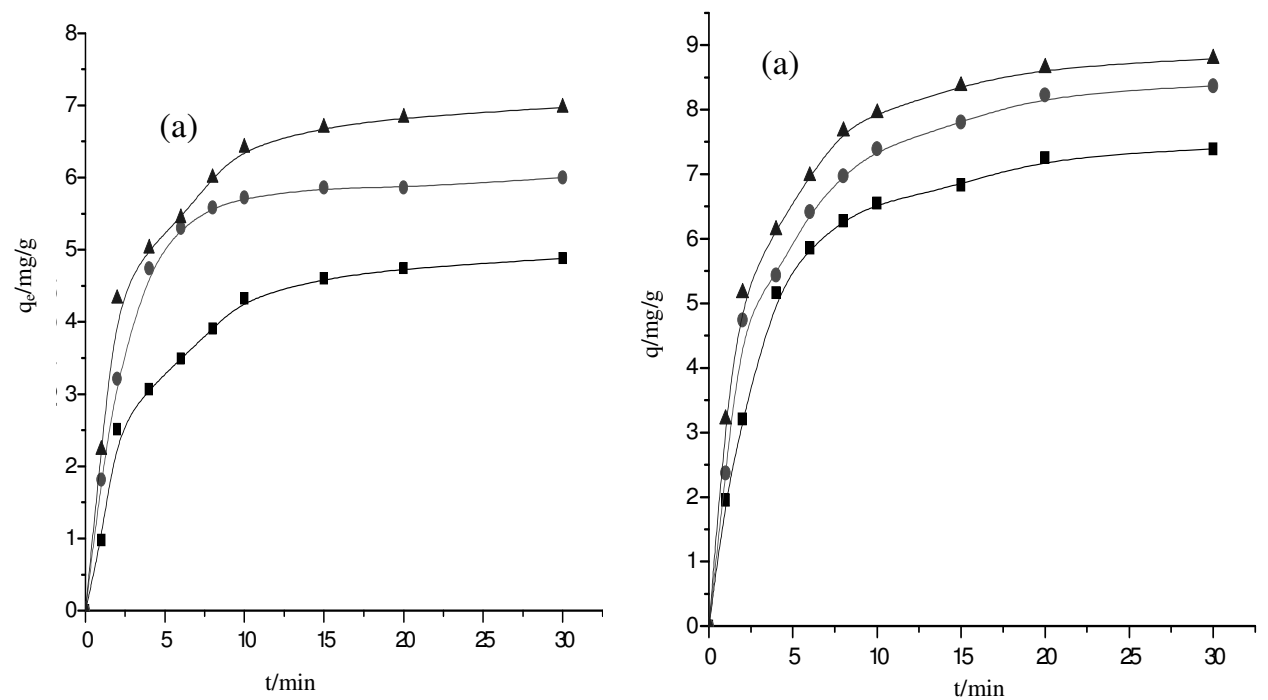


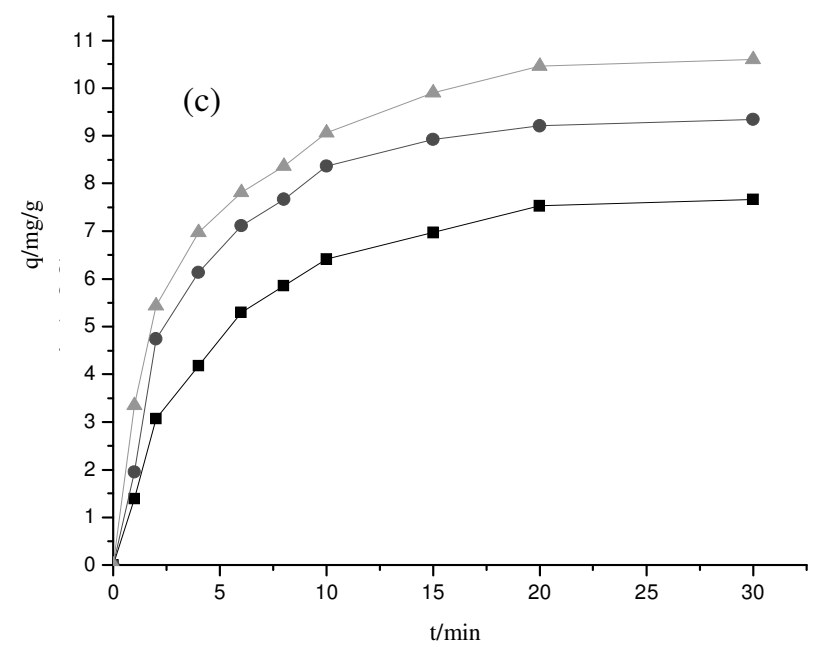

Figure 4. Influence of PVA (500) concentration and temperature on adsorbance, (a) $50 \mathrm{mg} / \mathrm{L}$, (b) $100 \mathrm{mg} / \mathrm{L}$, (c) $200 \mathrm{mg} / \mathrm{L} ;(\boldsymbol{\bullet}) 25^{\circ} \mathrm{C},(\bullet) 35^{\circ} \mathrm{C},(\boldsymbol{\Delta}) 45^{\circ} \mathrm{C}$
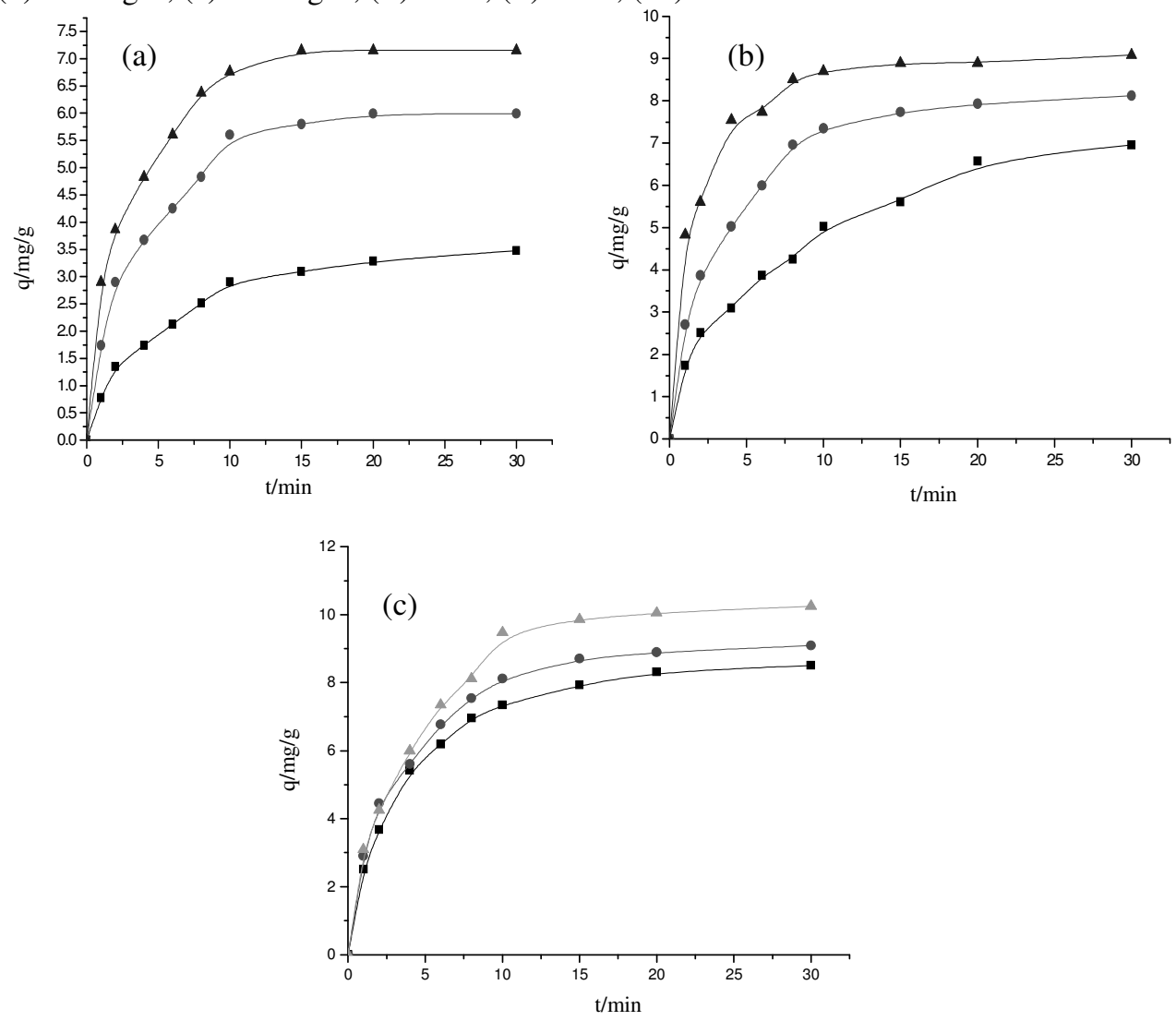

Figure 5. Influence of PVA (700) concentration and temperature on adsorbance, (a) $50 \mathrm{mg} / \mathrm{L}$, (b) $100 \mathrm{mg} / \mathrm{L}$, (c) $200 \mathrm{mg} / \mathrm{L} ;(\mathbf{\square}) 25^{\circ} \mathrm{C},(\bullet) 35^{\circ} \mathrm{C},(\boldsymbol{\Delta}) 45^{\circ} \mathrm{C}$ 


\section{Adsorption kinetic models}

Both pseudo first- and second-order adsorption models are used to describe the adsorption kinetics data ${ }^{30,31}$. In both models, all the steps of adsorption such as external diffusion, internal diffusion and adsorption are lumped together and it is assumed that the difference between the average solid phase concentration and the equilibrium concentration is the driving force for adsorption and the complete adsorption rate is proportional to either the driving force (as in the pseudo first-order equation) or the square of the driving force (as in the pseudo second-order equation).

$$
\begin{gathered}
\text { First-order model : } \ln \left(q_{e}-q\right)=\ln q_{e}-k t \\
\text { Second-order model : } t / q=1 /\left(k q_{e}^{2}\right)+t / q_{e}
\end{gathered}
$$

$K$ : Adsorption rate constant $\left(\mathrm{min}^{-1}\right.$ for first-order adsorption, $\mathrm{g} \cdot \mathrm{mg}^{-1} \cdot \mathrm{min}^{-1}$ for secondorder adsorption); $t$ : Adsorption time (min)

Since $q$ reaches $q_{\mathrm{e}}$ at equilibrium, $q$ values smaller than $0.9 q_{\mathrm{e}}$ are used for analysis. Plots of $\ln \left(q_{\mathrm{e}}-q\right)$ versus $t$ and $t / q$ versus $t$ are used to test the first- and second-order models and the fitting results are given in Table 5 and Table 6 . Both line curve fit and $q_{\mathrm{e}, \text { cal }}$, second-order model gives more well results than first-order model. Second-order model is more suitable to describe the adsorption kinetics data. Similar results were observed in the adsorption of PEG on $\mathrm{EG}^{25}$.

\begin{tabular}{|c|c|c|c|c|c|c|c|c|}
\hline \multirow{2}{*}{$\begin{array}{l}C_{0}, \\
\mathrm{mg}\end{array}$} & \multirow[b]{2}{*}{$T,{ }^{o} \mathrm{C}$} & \multirow[b]{2}{*}{$\begin{array}{l}q_{e, \exp } \\
\mathrm{mg} / \mathrm{g}\end{array}$} & \multicolumn{3}{|c|}{ First-order } & \multicolumn{3}{|c|}{ Second-order } \\
\hline & & & $\begin{array}{l}q_{e, c a l} \\
\mathrm{mg} / \mathrm{g}\end{array}$ & $\begin{array}{c}k, \\
1 / \min \end{array}$ & $r$ & $\begin{array}{l}q_{e, c a l}, \\
\mathrm{mg} / \mathrm{g}\end{array}$ & $\begin{array}{c}k, \\
\mathrm{~g} / \mathrm{g} \cdot \min \end{array}$ & $r$ \\
\hline \multirow{3}{*}{50} & 25 & 4.88 & $\begin{array}{c}4.00 \\
\pm 1.083\end{array}$ & $\begin{array}{c}0.176 \\
\pm 0.008\end{array}$ & -0.992 & $\begin{array}{c}5.102 \pm \\
0.067\end{array}$ & $0.093 \pm 0.0148$ & 0.999 \\
\hline & 35 & 5.997 & $\begin{array}{c}3.453 \\
\pm 1.028\end{array}$ & $\begin{array}{c}0.199 \\
\pm 0.027\end{array}$ & -0.940 & $\begin{array}{c}6.172 \pm \\
0.067\end{array}$ & $0.129 \pm 0.026$ & 0.999 \\
\hline & 45 & 7.113 & $\begin{array}{c}4.838 \\
\pm 1.125 \\
\end{array}$ & $\begin{array}{c}0.190 \\
\pm 0.012 \\
\end{array}$ & -0.986 & $\begin{array}{c}7.209 \pm 0 \\
.0 .061 \\
\end{array}$ & $0.137 \pm 0.011$ & 0.999 \\
\hline \multirow{3}{*}{100} & 25 & 7.671 & $\begin{array}{c}4.467 \\
\pm 1.176\end{array}$ & $\begin{array}{c}0.109 \\
\pm 0.012\end{array}$ & -0.953 & $\begin{array}{c}8.012 \\
\pm 0.056\end{array}$ & $0.503 \pm 0.003$ & 0.999 \\
\hline & 35 & 8.508 & $\begin{array}{c}5.486 \\
\pm 1.135\end{array}$ & $\begin{array}{c}0.135 \\
\pm 0.010\end{array}$ & -0.980 & $\begin{array}{c}8.863 \pm 8 . \\
56 \mathrm{E}-4\end{array}$ & $0.530 \pm 0.004$ & 0.999 \\
\hline & 45 & 8.926 & $\begin{array}{r}5.093 \\
\pm 1.165 \\
\end{array}$ & $\begin{array}{c}0.135 \\
\pm 0.011 \\
\end{array}$ & -0.972 & $\begin{array}{c}9.213 \pm \\
0.043 \\
\end{array}$ & $0.065 \pm 0.004$ & 1.000 \\
\hline \multirow{3}{*}{200} & 25 & 7.810 & $\begin{array}{c}6.338 \\
\pm 1.099\end{array}$ & $\begin{array}{c}0.138 \\
\pm 0.007\end{array}$ & -0.989 & $\begin{array}{c}8.384 \\
\pm 0.132\end{array}$ & $\begin{array}{c}0.034 \\
\pm 0.004\end{array}$ & 0.999 \\
\hline & 25 & 9.484 & $\begin{array}{c}6.381 \\
\pm 1.153\end{array}$ & $\begin{array}{c}0.143 \\
\pm 0.011\end{array}$ & -0.978 & $\begin{array}{c}9.967 \\
\pm 0.142\end{array}$ & $0.042 \pm 0.006$ & 0.999 \\
\hline & 45 & 10.600 & $\begin{array}{c}6.381 \\
\pm 1.152\end{array}$ & $\begin{array}{c}0.194 \pm \\
0.011\end{array}$ & -0.988 & $\begin{array}{c}11.08 \pm \\
0.113\end{array}$ & $\begin{array}{c}0.043 \pm \\
0.005\end{array}$ & 0.999 \\
\hline
\end{tabular}

Table 5. Comparison of the adsorption kinetic models of PVA (500) on EG 
Table 6. Comparison of the adsorption kinetic models of PVA (700) on EG

\begin{tabular}{|c|c|c|c|c|c|c|c|c|}
\hline \multirow{2}{*}{$\begin{array}{c}C_{0}, \\
\mathrm{mg} / \mathrm{L}\end{array}$} & \multirow{2}{*}{$\begin{array}{l}T, \\
{ }^{\circ} \mathrm{C}\end{array}$} & \multirow[b]{2}{*}{$\begin{array}{l}q_{e, e x p} \\
\mathrm{mg} / \mathrm{g}\end{array}$} & \multicolumn{3}{|c|}{ First-order } & \multicolumn{3}{|c|}{ Second-order } \\
\hline & & & $\begin{array}{l}q_{e, c a l} \\
\mathrm{mg} / \mathrm{g}\end{array}$ & $\begin{array}{c}k, \\
1 / \mathrm{min}\end{array}$ & $r$ & $\begin{array}{l}q_{e, c a l}, \\
\mathrm{mg} / \mathrm{g}\end{array}$ & $\begin{array}{c}k, \\
\mathrm{~g} / \mathrm{g} \cdot \min \end{array}$ & $r$ \\
\hline \multirow{3}{*}{50} & 25 & 3.674 & $\begin{array}{c}2.821 \\
\pm 1.083\end{array}$ & $\begin{array}{c}0.097 \\
\pm 0.008\end{array}$ & -0.983 & $\begin{array}{c}3.952 \\
\pm 0.067\end{array}$ & $\begin{array}{c}0.059 \\
\pm 0.015\end{array}$ & 1.000 \\
\hline & 35 & 5.994 & $\begin{array}{c}5.735 \\
\pm 1.028\end{array}$ & $\begin{array}{c}0.229 \\
\pm 0.027\end{array}$ & -0.983 & $\begin{array}{c}6.297 \\
\pm 0.067\end{array}$ & $\begin{array}{c}0.073 \\
\pm 0.026\end{array}$ & 0.999 \\
\hline & 45 & 7.154 & $\begin{array}{c}6.508 \\
\pm 1.125\end{array}$ & $\begin{array}{c}0.290 \pm \\
0.012\end{array}$ & -0.989 & $\begin{array}{c}7.390 \\
\pm 0.061\end{array}$ & $\begin{array}{c}0.099 \\
\pm 0.019\end{array}$ & 0.999 \\
\hline \multirow{3}{*}{100} & 25 & 7.153 & $\begin{array}{c}2.451 \\
\pm 1.062\end{array}$ & $\begin{array}{c}0.116 \pm \\
0.005\end{array}$ & -0.994 & $\begin{array}{c}7.836 \pm \\
0.184\end{array}$ & $\begin{array}{c}0.025 \\
\pm 0.003\end{array}$ & 0.998 \\
\hline & 35 & 8.121 & $\begin{array}{c}2.811 \\
\pm 1.185\end{array}$ & $\begin{array}{c}0.117 \\
\pm 0.030\end{array}$ & -0.993 & $\begin{array}{c}8.968 \\
\pm 0.111\end{array}$ & $\begin{array}{l}0.0872 \\
\pm 0.019\end{array}$ & 0.999 \\
\hline & 45 & 9.281 & $\begin{array}{c}3.661 \\
\pm 1.295\end{array}$ & $\begin{array}{c}0.118 \\
\pm 0.020\end{array}$ & -0.905 & $\begin{array}{c}9.443 \pm \\
0.035\end{array}$ & $\begin{array}{c}0.098 \\
\pm 0.005\end{array}$ & 1.000 \\
\hline \multirow{3}{*}{200} & 25 & 8.507 & $\begin{array}{c}7.115 \\
\pm 1.060\end{array}$ & $\begin{array}{c}0.179 \\
\pm 0.006\end{array}$ & -0.996 & $\begin{array}{c}8.934 \\
\pm 0.094\end{array}$ & $\begin{array}{c}0.049 \\
\pm 0.005\end{array}$ & 1.000 \\
\hline & 35 & 9.087 & $\begin{array}{c}7.437 \\
\pm 1.064\end{array}$ & $\begin{array}{c}0.191 \\
\pm 0.006\end{array}$ & -0.996 & $\begin{array}{c}9.498 \\
\pm 0.103\end{array}$ & $\begin{array}{c}0.052 \\
\pm 0.006\end{array}$ & 0.999 \\
\hline & 45 & 10.247 & $\begin{array}{c}9.246 \\
\pm 1.117\end{array}$ & $\begin{array}{c}0.194 \\
\pm 0.011\end{array}$ & -0.988 & $\begin{array}{l}10.792 \\
\pm 0.164\end{array}$ & $\begin{array}{c}0.055 \\
\pm 0.012\end{array}$ & 0.999 \\
\hline
\end{tabular}

Based on the second-order model, initial adsorption rate and half-adsorption time are estimated according to equations (8) and (9). As showed in Table 7 and Table 8, $u$ is found to increase with the increase of temperature and $t_{1 / 2}$ decrease with the increase of temperature.

$$
\begin{gathered}
u=k q_{e}{ }^{2} \\
t_{l / 2}=1 /\left(k q_{e}\right)
\end{gathered}
$$

where $u=$ Initial adsorption rate, $(\mathrm{mg} / \mathrm{g} \cdot \mathrm{min}) ; t_{1 / 2}=$ Half-adsorption time, $\mathrm{min}$

Second-order rate constants are used to calculate activation energy of PVA adsorption on EG using Arrhenius equation ${ }^{32}$ :

$$
\operatorname{Lnk}=\operatorname{LnA}-E a /(R T)
$$

$A$ : The re-exponential factor, $\left(\mathrm{g} \cdot \mathrm{mg}^{-1} \cdot \mathrm{min}^{-1}\right) ; E a$ : The activation energy of adsorption, $(\mathrm{kJ} / \mathrm{mol})$

Slope of lnk versus $1 / T$ is used to evaluate $E$ a, which is found less than $20.0 \mathrm{~kJ} \cdot \mathrm{mol}^{-1}$ (as showed in Table 7 and Table 8). So, the adsorption is mainly physical adsorption.

\section{Internal diffusion analysis}

Among the external diffusion, internal diffusion and actual adsorption of the adsorption process, the long adsorption equilibrium time of PVA on EG (20 60 min corresponding to adsorption temperature of $25 \sim 45^{\circ} \mathrm{C}$ ) suggests that the internal diffusion may dominate the overall adsorption kinetics. To provide definite information on the rate-limiting step, an internal diffusion model based on fick's second law is used to test if the internal diffusion step is the rate-limiting step ${ }^{33}$ :

$$
\begin{gathered}
q=k_{i d} t^{1 / 2} \\
k_{i d} \text { : Internal diffusion constant, }\left(\mathrm{mg} / \mathrm{g} \cdot \mathrm{min}^{1 / 2}\right)
\end{gathered}
$$


Table 7. Kinetic parameters for the second-order adsorption model of PVA (500)

\begin{tabular}{cccccc}
\hline$C_{0,}, \underline{m g / g}$ & $T^{\circ} \mathrm{C}$ & $u, \mathrm{mg} / \mathrm{g} \cdot \min$ & $t_{1 / 2}, \min$ & $E_{a}, \mathrm{~kJ} / \mathrm{mol}$ & $r$ \\
\multirow{3}{*}{50} & 25 & 2.415 & 2.209 & & \\
& 35 & 3.299 & 1.297 & $15.61 \pm 5.63$ & 0.941 \\
& 45 & 4.677 & 1.043 & & \\
\multirow{3}{*}{100} & 25 & 3.230 & 2.590 & & \\
& 35 & 4.164 & 2.167 & $9.81 \pm 3.53$ & 0.941 \\
& 45 & 5.488 & 1.733 & & \\
200 & 25 & 2.396 & 2.755 & & \\
& 35 & 4.155 & 2.521 & $8.85 \pm 4.07$ & 0.908 \\
& 45 & 5.233 & 2.215 & & \\
\hline
\end{tabular}

Table 8. Kinetic parameters for the second-order adsorption model of PVA (700)

\begin{tabular}{cccccc}
\hline$C_{0}, \mathrm{mg} / \mathrm{g}$ & $T,{ }^{\circ} \mathrm{C}$ & $u, \mathrm{mg} / \mathrm{g} \cdot \min$ & $t_{1 / 2}, \min$ & $E_{a}, \mathrm{~kJ} / \mathrm{mol}$ & $r$ \\
\hline \multirow{2}{*}{50} & 25 & 0.915 & 4.468 & & \\
& 35 & 2.912 & 2.271 & $20.52 \pm 1.94$ & 0.996 \\
& 45 & 5.388 & 1.417 & & \\
\multirow{2}{*}{100} & 25 & 1.517 & 5.656 & & \\
& 35 & 7.009 & 1.319 & $23.6 \pm 7.7$ & 0.910 \\
& 45 & 8.762 & 1.097 & & \\
\multirow{2}{*}{200} & 25 & 3.875 & 2.422 & & 1.000 \\
& 35 & 4.678 & 2.122 & $5.01 \pm 0.032$ & \\
\hline
\end{tabular}

According to the internal diffusion model, the plot of $q$ versus $t^{1 / 2}$ should give a straight line with a slope $k_{\text {id }}$ and an intercept of zero if the adsorption is limited by the internal diffusion process. The relationships between $q$ of PVA $(500,700)$ and $t^{1 / 2}$ at different temperature are showed in Figure 6 and Figure 7. In the range of the tested temperature, a linear relationship between $q$ versus $t^{1 / 2}$ with a zero intercept is found when the adsorption temperature is high. Increase of temperature can decrease the viscosity of PVA solution and reduce the external diffusion and then internal diffusion is control step.

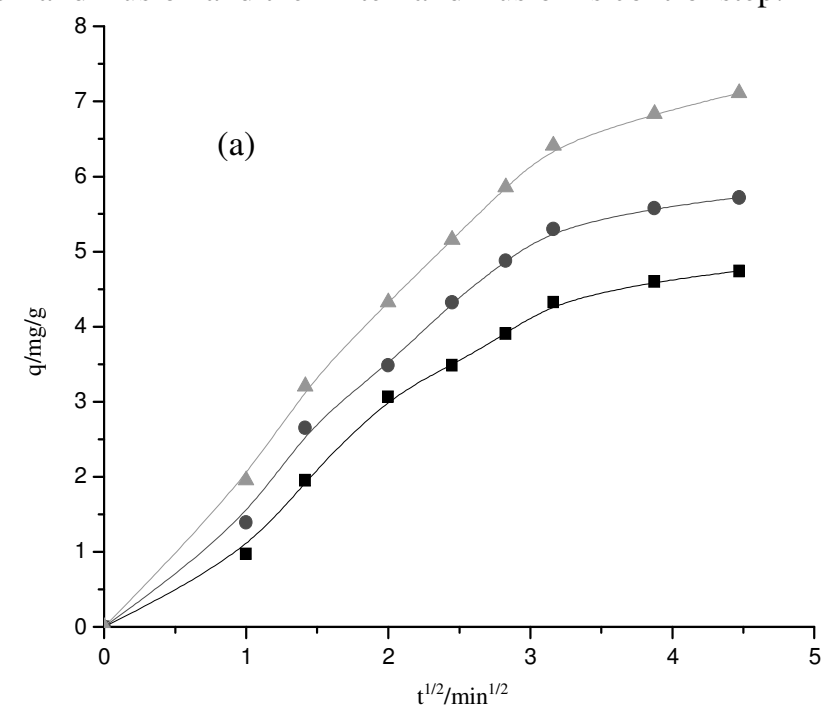



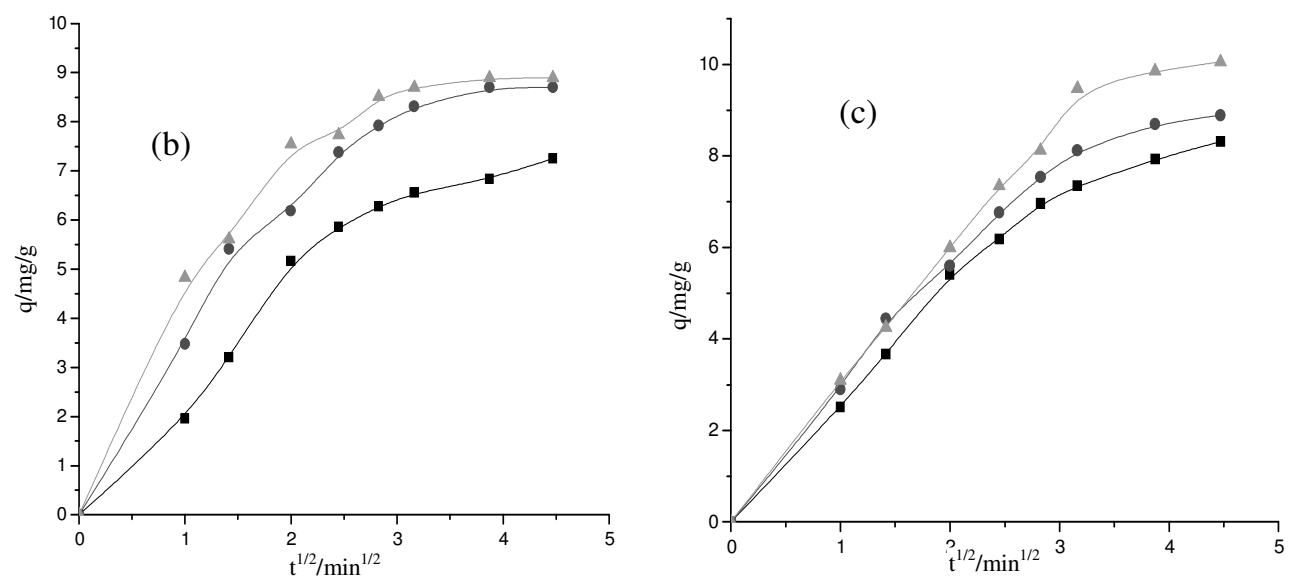

Figure 6. Plot of $q$ vs. $t^{1 / 2}$ in internal diffusion model of PVA (500), (a) $50 \mathrm{mg} / \mathrm{L}$, (b) $100 \mathrm{mg} / \mathrm{L}$, (C) $200 \mathrm{mg} / \mathrm{L},(\boldsymbol{\bullet}) 25{ }^{\circ} \mathrm{C},(\bullet) 35^{\circ} \mathrm{C},(\boldsymbol{\Delta}) 45^{\circ} \mathrm{C}$
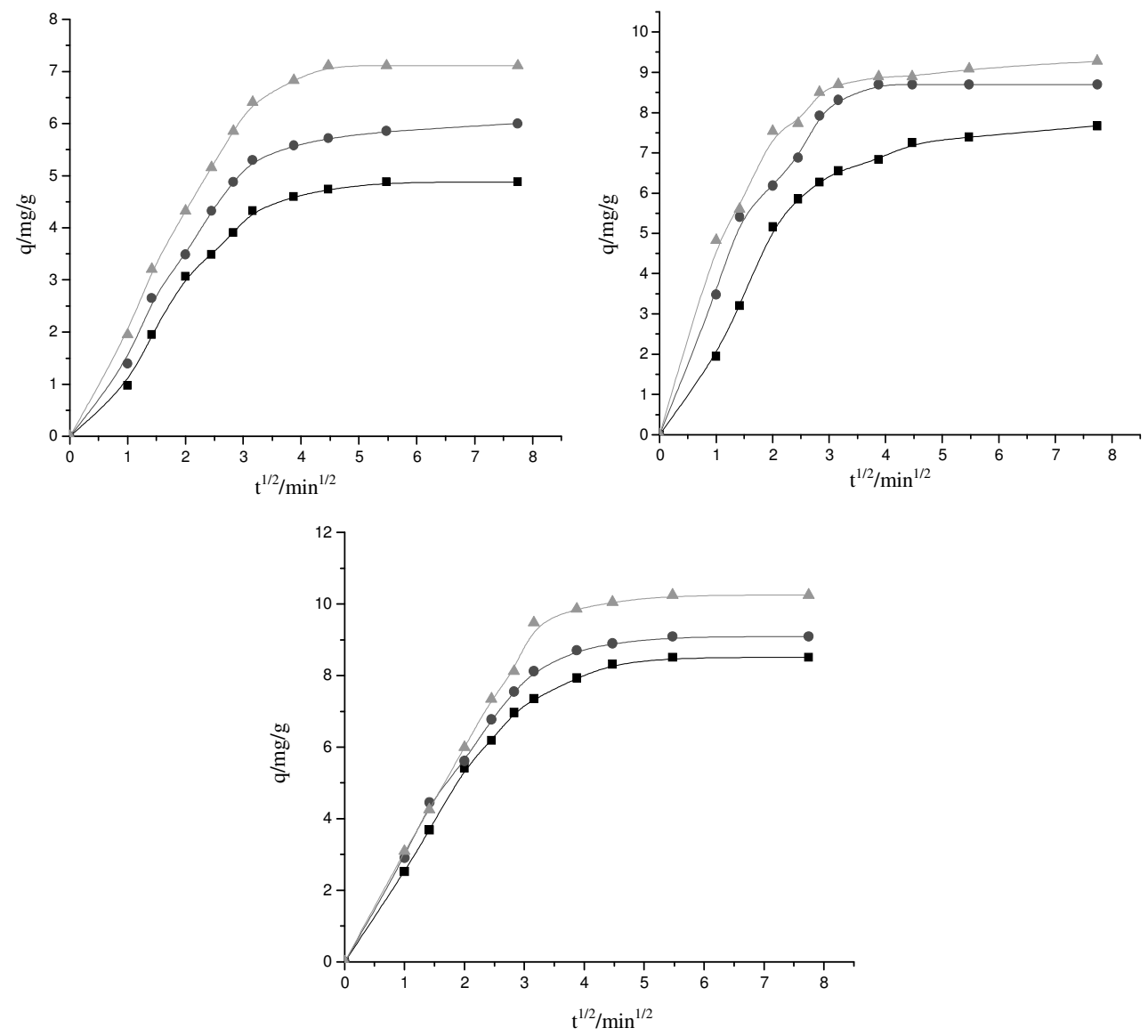

Figure 7. Plot of $q$ vs. $t^{1 / 2}$ in internal diffusion model of PVA (700), (a) $50 \mathrm{mg} / \mathrm{L}$, (b) $100 \mathrm{mg} / \mathrm{L}$, (c) $200 \mathrm{mg} / \mathrm{L}$; (匹) $25^{\circ} \mathrm{C},(\bullet) 35^{\circ} \mathrm{C},(\boldsymbol{\Delta}) 45^{\circ} \mathrm{C}$ 


\section{Conclusion}

Adsorption of EG for PVA with different DPs have been investigated. The results are summarized as follows:

- Adsorption isotherms of EG for PVA can be well described with Langmuir equation, and the present of $\mathrm{SO}_{4}{ }^{2-}$ can improve the adsorbance.

- Adsorption of EG for PVA is spontaneous, adsorption isotherms of PVA (500, 700, 1750) are all type I and PVA molecule lies flat on EG surface.

- Adsorption kinetics of EG for PVA can be described by pseudo-second-order model equation. Equilibrium time and half-adsorption time t1/2 decreases with the increase of temperature. The adsorption belongs to physical adsorption and internal diffusion is tested to be the rate-limiting step of the complete adsorption process.

\section{Acknowledgment}

This study was supported by Doctor Foundation of Hebei province Education Office (China, No.B2004402) and Doctor Foundation of Hebei University. We gratefully acknowledge their support during the study.

\section{Reference}

1. Du J R, Peldszus S, Huck P M and Feng X S, Water Res., 2009, 43, 4559

2. Peng S J, Gao Z Q, Sun J, Yao L and Qiu Y P, Appl Surf Sci., 2009, 255, 9458.

3. Lee J A and Kim M N, Polym Degrad Stabil., 2003, 81(2), 303-308.

4. Tsujiyama S I, Nitta T and Maoka T, J Biosci Bioeng., 2011, 112, 58.

5. Chen J, Zhang Y, Du G C, Hua Z Z and Zhu Y, Enzyme Microb Technol., 2007, 40, 1686.

6. Porter J J, J Membr Sci., 1998, 151(1), 45-53.

7. Dong S X, Gong Q, Zhao S Y and Wang E L, J Text., 2004, 25, 73.

8. Lin S H and Lan W J, Sep Technol., 1995, 5, 97.

9. Tadros T F, J Colloid Interface Sci., 1978, 64, 36.

10. Tadros T F and Vincent B, J Colloid Interface Sci., 1978, 72, 505.

11. Backfolk K, Rosenholm J B, Husband J and Eklund D, Colloid Surf A: Physicochem. Eng Aspects, 2006, 275, 133-141.

12. Bajpai A K and Vishwakarma N, Colloid Surf A: Physicochem Eng Aspects, 2003, 220, 117-130.

13. Bussetti S G and Fereiro E A, Clays Clay Miner., 2004, 52, 334-340.

14. Behera S K, Kim J H, Guo X and Park H S, Hazard Mater., 2008, 153, 1207-1214.

15. Zhao H, Zhou W, Cao N Z, Shen W C and Zheng Y P, Mater Sci Eng., 2002, 20(2), 153-156.

16. Kang F Y, Zheng Y P, Zhao H, Wang H N, Wang L N, Shen W C and Inagaki M, New Carbon Mater., 2003, 18(3), 161.

17. Toyoda M, Moriya K, Aizawa J I, Konno H and Michio I, Desalination, 2000, 128(3), 205-211.

18. Inagaki M, Konno H, Toyoda M, Moriya K and Kihara T, Desalination, 2000, 128, 213-218.

19. Inagaki M, Shibata K, Setou S, Toyoda M and Aizawa J I, Desalination, 2000, 128(3), 219-222.

20. Toyoda M, Nishi Y, Iwashita N and Inagaki M, Desalination, 2003, 151(2), 139-144.

21. Inagaki M, Nagata T, Suwa T and Toyoda M, New Carbon Mater., 2006, 21(2), 97-102.

22. Pang X Y, Ren H L, Gong F and You T T, J Hebei Univ (Nat. Sci)., 2008, 28(5), 512.

23. Pang X Y, Lv P, Feng Y Q and Liu X W, Environ Sci an Indian J., 2008, 3(2), 150-157. 
24. Pang X Y, Su Y J, Lv P, Ren H L and Gong F, J Hebei Univ. (Nat Sci.), 2010, 30, 37.

25. Pang X Y, E- J Chem., 2010, 7(4), 1258-1265.

26. Cao N Z, Shen W C, Liu Y J and Wen S Z, China Carbon, 1995, 3, 9.

27. Shao Z H, Zhou M H and Lei L C, Acta Scientiae Circumstantiate, 2005, 25(5), 655.

28. Gupta V K, Ali I, Suhas and Mohan D, J Colloid Interf Sci., 2003, 265, 257.

29. Wu Z J, Hyeonwoo J and Kang T L, Chem Eng J., 2005, 112, 227.

30. Chiou M S and Li H Y, Chemosphere, 2003, 50(8), 1095-1105.

31. Chiou M S and Li H Y, J Hazard Mater., 2002, 93, 233.

32. Sarkar M, Acharya P K and Bhattacharya B, J Colloid Interf Sci., 2003, 266(1), 28-32.

33. Mak S Y and Chen D H, Dyes Pigments, 2004, 61, 93-98. 


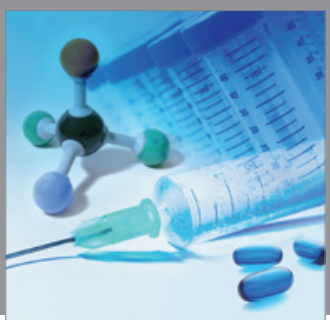

International Journal of

Medicinal Chemistry

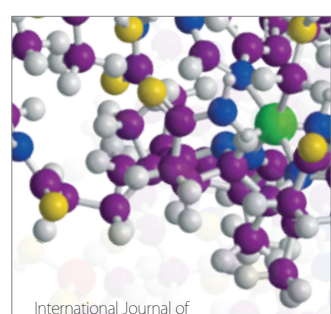

Carbohydrate Chemistry

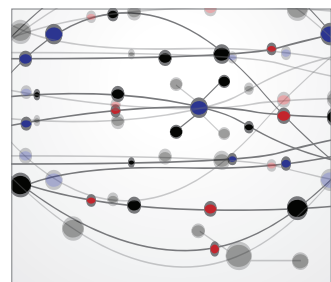

The Scientific World Journal
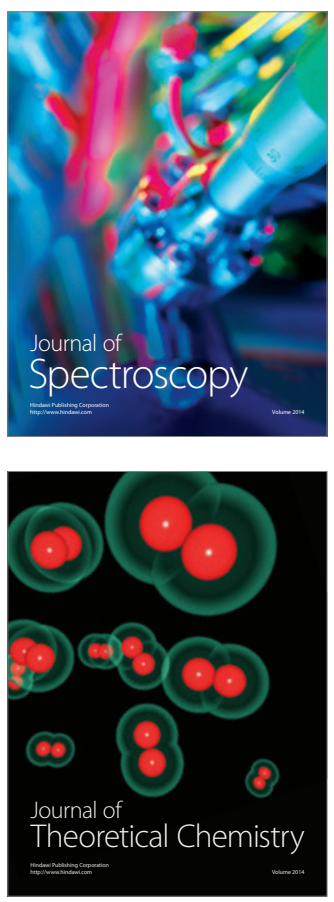
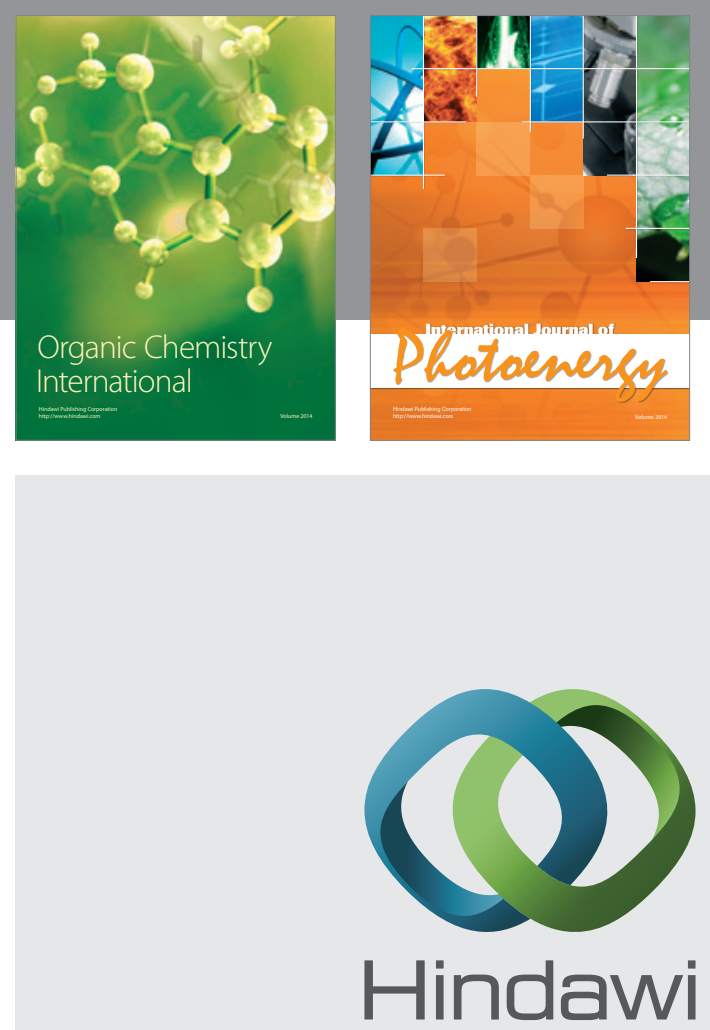

Submit your manuscripts at

http://www.hindawi.com
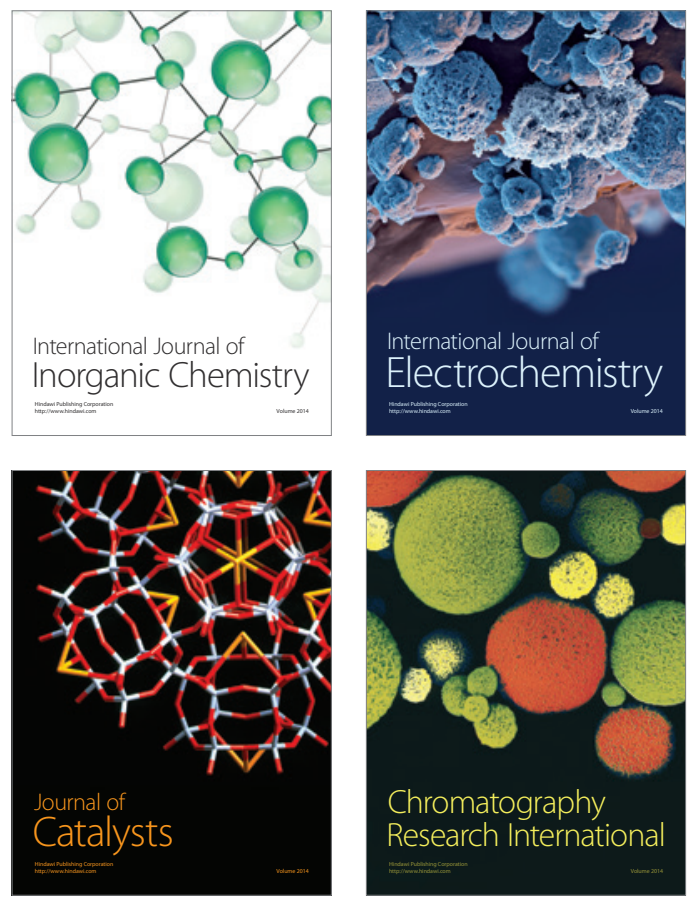
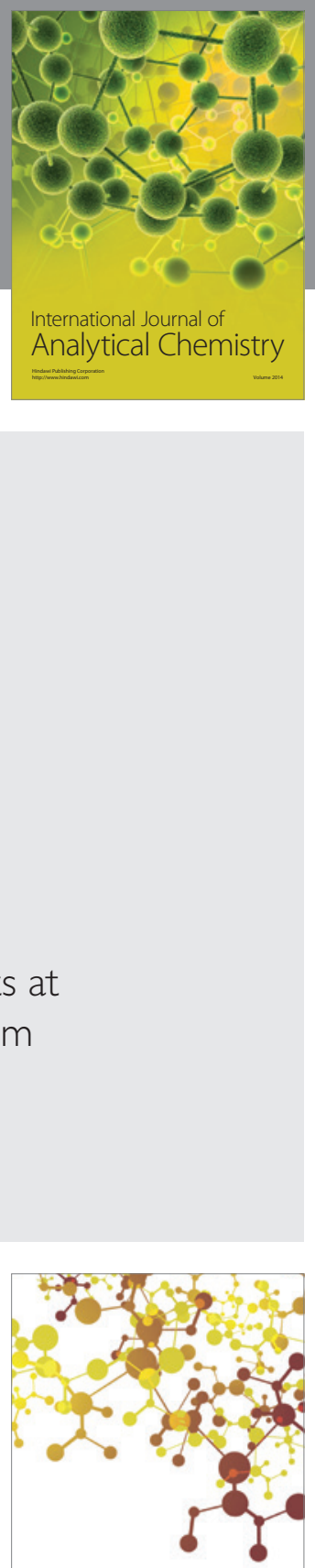

Journal of

Applied Chemistry
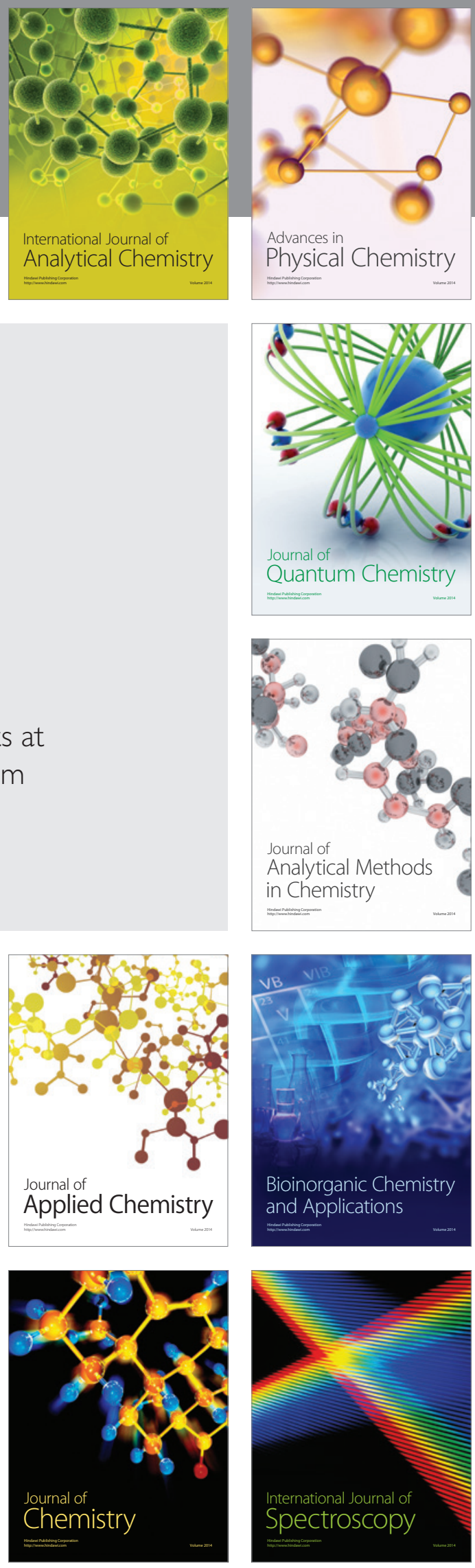